\title{
Unexpected cause of recurrent epistaxis
}

\author{
Jose Luis Camacho-Velásquez, Elena Rivero-Sanz, Carlos Tejero-Juste
}

Department of Neurology, Hospital Clinico Universitario Lozano Blesa, Zaragoza, Spain

\section{Correspondence to}

Dr Elena Rivero-Sanz, ella789@hotmail.com

Accepted 4 November 2015

\section{(a) CrossMark}

To cite: Camacho-

Velásquez JL, Rivero-Sanz E, Tejero-Juste C. BMJ Case Rep Published online: [please include Day Month Year] doi:10.1136/bcr-2015213021

\section{DESCRIPTION}

A 76-year-old man with a medical history of laryngeal cancer (T2N0M0), treated with radiotherapy and surgical excision (open partial laryngectomy) 20 years previously, and currently undergoing investigations for haematemesis, attended the emergency department after undergoing a week of recurrent epistaxis sometimes associated with hypotension and syncope. On examination, he had normal rhinoscopy findings. Blood tests revealed anaemia (haemoglobin $6 \mathrm{~g} / \mathrm{dL}$ ) with normal coagulation tests. After stabilising the patient with a blood transfusion, an oesophagogastroduodenoscopy was conducted, which revealed blood clots in the oesophagus, without a clear ulcer, wound or varices. The patient underwent an arteriographythe image showed a left carotid oesophageal fistula (figure 1, left).

Causes of carotid-oesophageal fistula can result from arterial lesions; mediastinitis; ${ }^{1}$ a foreign body, such as a fishbone, in the oesophagus, ${ }^{2}$ which can result in Chiari's triad (chest pain, upper gastrointestinal bleeding and anaemia); or malignant lesions from adjacent organs (such as the oesopha-

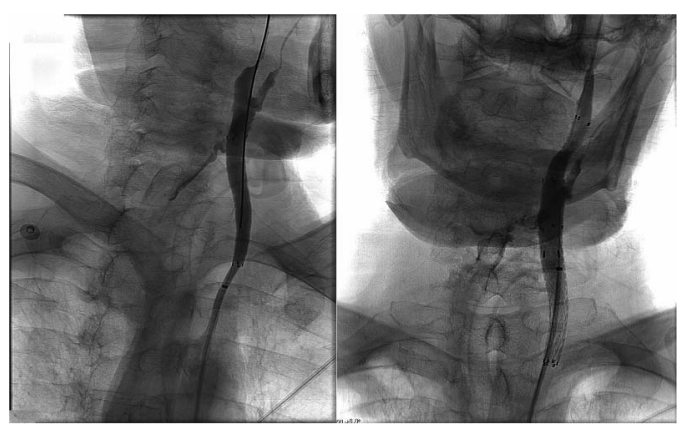

Figure 1 Arteriography showing a left carotid oesophageal fistula (left), where three stents were inserted, resulting in complete fistula closure (right). gus); they can also occur in those previously (even many years before, as in this case) treated with radiotherapy.

Tracheo-oesophageal fistula was excluded due to the absence of contrast in the trachea after the imaging. Arteriovenous malformation was also discarded because there were no vascular bundles or arteriovenous circulation suggestive of this on arteriography.

The patient was subsequently taken to interventional radiology where three stents were inserted, resulting in complete fistula closure without complications (figure 1, right). The patient made a good recovery, and was discharged a few days later, scheduled for regular follow-up.

\section{Learning points}

- There are many causes of tracheo-oesophageal fistula, one of the most common is due to laryngectomy and radiotherapy.

- Chiari's triad is a clinical finding that could be present in tracheo-oesophageal fistula.

Contributors JLC-V and ER-S were involved in writing the case and searching the literary review. CT-J was involved in supervising the project.

Competing interests None declared.

Patient consent Obtained.

Provenance and peer review Not commissioned; externally peer reviewed.

\section{REFERENCES}

1 Kimura N, Takada K, Murata K, et al. A case of Behçet's disease complicated by carotid-oesophageal fistula. Rheumatology (Oxford) 2014;53:196-8.

2 Mañas Gomez MJ, Castro Boix S. Carotid-oesophageal fistula due to foreign body. Cir Esp 2012;90:668-78.

Copyright 2015 BMJ Publishing Group. All rights reserved. For permission to reuse any of this content visit

http://group.bmj.com/group/rights-licensing/permissions.

BMJ Case Report Fellows may re-use this article for personal use and teaching without any further permission.

Become a Fellow of BMJ Case Reports today and you can:

- Submit as many cases as you like

- Enjoy fast sympathetic peer review and rapid publication of accepted articles

- Access all the published articles

- Re-use any of the published material for personal use and teaching without further permission

For information on Institutional Fellowships contact consortiasales@bmjgroup.com

Visit casereports.bmj.com for more articles like this and to become a Fellow 